\title{
Inflorescence Position Influences Phenological Rhythms in Leguminosae Species
}

\author{
Alexsandro Bezerra-Silva ${ }^{1}$ (1) \\ Adelly Cardoso de Araujo Fagundes ${ }^{1}$ (i) \\ Maria Thereza Dantas Gomes ${ }^{1}$ (i) \\ Isiara Silva Menezes ${ }^{1}$ (1) \\ Ana Paula Lima do Couto-Santos ${ }^{2}$ (C) \\ Carlianne Oliveira Cerqueira ${ }^{3}$ \\ Lia D’Afonsêca Pedreira de Miranda ${ }^{1}$ \\ Ligia Silveira Funch ${ }^{1}$ (])
}

\begin{abstract}
${ }^{1}$ Universidade Estadual de Feira de Santana (UEFS), Departamento de Ciências Biológicas, Feira de Santana, BA, Brasil. ${ }^{2}$ Universidade Estadual do Sudoeste da Bahia (UESB), Departamento de Ciências Exatas e Naturais, Itapetinga, BA, Brasil. ${ }^{3}$ Centro Estadual de Educação Profissional em Saúde do Centro Baiano, Feira de Santana, BA, Brasil.
\end{abstract}

\begin{abstract}
We present a case study focusing on the influence of inflorescence position on the relationships between foliar and reproductive phases, focusing on three Leguminoseae tree species in the Chapada Diamantina, Brazil. Both Senna multijuga and Copaifera langsdorffii produce terminal panicles and showed vegetative and reproductive phenophases that were correlated but segregated in time, with the marked concentration of reproductive data. The presence of axillary inflorescences on Inga cayennensis enables the simultaneous production of both flowers and leaves, without the segregation or the correlation of those phases, with a uniform distribution of reproductive data. This study encourages further investigations regarding the effects of inflorescence position on plant phenology.
\end{abstract}

Keywords: phenology, tropical trees, Copaifera langsdorffii, Inga cayennensis, Senna multijuga.

The phenological rhythms of tropical trees can be influenced by environmental variables, biotic interactions, and plant traits that can modulate the rhythms of leaf exchange, flowering, and fruiting (Morellato et al., 2016). Among plant traits, terminal or axillary positions of the flower/inflorescence will affect the very construction of the plant (Weberling, 1989; Bell, 1991), but have not been examined in phenological studies. Flowers/ terminal inflorescences are formed from the apical meristem in a process that halts meristematic activity; flowers/axillary inflorescences, on the other hand, are formed by lateral meristems, a situation that allows continuous activity of the apical meristem, and therefore vegetative growth (Weberling, 1989; Bell, 1991).

We accompanied the phenology of three Leguminoseae tree species in an Atlantic Forest fragment in the Chapada Diamantina Mountains in Brazil to investigate the influence of the position of the inflorescence on the relationships between foliar and reproductive phases. Copaifera langsdorffii Desf. ("copaíba" or "pau dóleo") is distributed from Argentina to Venezuela, grows widely in Brazil, and produces terminal inflorescences (Costa, 2020). Senna multijuga (Rich.) H.S. Irwin \& R. C. Barneby ("canafístula") is found from South America to Mexico, is widely distributed in Brazil, and produces terminal inflorescences (Bortoluzzi et al., 2020). Inga cayenennsis Sagot ex Benth. ("monkey ingá") is endemic to Brazil, occurs in the northern and northeastern regions of that country, and produces axillary inflorescences (Garcia \& Bonadeu, 2020). We hypothesized that plants with axillary flowers or inflorescences can have simultaneous foliar and reproductive phases, without any correlation between them, and a low concentration of data, indicating a tendency of uniform distribution. In contrast, plants with terminal flowers or inflorescences must have a temporal segregation between their foliar and reproductive phases, with significant correlations between them, and varying amounts of data concentration, indicating aggregated phenological activities. 
The study site was located in a fragment of cloud forest covering approximately 6.7 ha on the Serra da Bacia Mountain $\left(12^{\circ} 27^{\prime} 49^{\prime \prime} \mathrm{S}-41^{\circ} 28 \times 34^{\prime \prime} \mathrm{W}\right)$, at approximately 1000 masl, Bahia State, Brazil. The region has a tropical climate (type Aw by the Köppen system), with a rainy season concentrated in the austral summer (November-April) and a dry winter season (June-October) (Alvares et al., 2014). Climatological data of precipitation, temperature and air humidity were obtained from the National Institute of Meteorology (INMET) for the period between 2006 and 2008 (Figure 1). Phenological observations were performed monthly on marked individuals of S. multijuga $(\mathrm{n}=7)$, C. langsdorffii $(\mathrm{n}=11)$, and I. cayennensis $(\mathrm{n}=7)$, from March/2006 to August/2008. Foliar (leaf fall and flushing) and reproductive (flowering and fruiting) phenophases were followed, with their intensities being estimated in classes of 0-4 (Fournier, 1974). We examined aggregation phenological data using circular statistics (Morellato et al., 2010; Santos et al., 2021) in the R environment, with the addition of the "circular" package 3.2.3 (R Core Team, 2014). The frequency of each phenophase was calculated based on the total number of individuals showing the phases per month. For each phenophase we calculated the length of the mean vector ( $r$ - the degree of temporal aggregation of phenophase activity) - with high $r$ values $(>0.5)$ indicating aggregated phenological activities. The Rayleigh test $(\mathrm{Z})$ determined if the data were distributed uniformly throughout the year $(p>0.05)$ (Zar, 2010). We examined correlations between leaf and reproductive phenophases data using Spearman's correlation coefficients (rs), calculated using BioStat 5.8.3.1 software (Orellana et al., 2021). The normality of the phenological data was tested based on Shapiro \& Wilk (Zar, 2010).

Copaifera langsdorffi showed temporal segregation between its leaf (dry season) and reproductive (rainy season) phases, with greater leaf fall between July and September (up to 30\% intensity), greater leaf flushing between September and October (up to $80 \%$ intensity), and flowering and fruiting between December and March 2008 (Figure 2). Leaf flushing, flowering and fruiting were seasonal (Table 1). There was a negative correlation among the phenophases of leaf flushing and flowering $(f=-0.44, p<0.05)$ as well as fruiting $(f=-0.55 ; p<0.05)$, with paired correlations. With a difference of one month, there was negative correlation between leaf fall and fruiting $(f=-0.38 ; p$ $<0.05)$. Inga cayennensis presented its leaf and reproductive phases simultaneously, without temporal segregation. Leaf flushing and leaf fall occurred almost continuously at low intensity (up to $25 \%$ ), while flowering and fruiting occurred seasonally at low intensity between December 2007 and July 2008 (Figure 2 ; Table 1). There were no correlations between phenophases. Senna multijuga exhibited temporal segregation between its leaf (dry season until the beginning of the rainy season) and reproductive phases (rainy season to the beginning of the dry season), with marked seasonality (Figure 2; Table 1), greater leaf fall activity (up to 60\% intensity) and budding (up to 30\% intensity) occurred between the months of June to March; flowering and fruiting were recorded in three episodes, with flowering beginning in February (peak in March) and fruiting from April to August (Figure 2). Among the phenophases, there was negative correlation between leaf flushing and fruiting ( $\mathrm{f}=-0.74 ; \mathrm{p}<0.05)$, as well as between leaf fall and flowering $(\mathrm{f}=-0.50 ; \mathrm{p}<0.05)$ and fruiting $(\mathrm{f}=-0.48 ; \mathrm{p}<0.05)$.

The results confirmed the initial hypothesis of this study, that in S. multijuga and C. langsdorffii (both producing terminal panicles) the vegetative and reproductive phenophases were correlated and segregated in time, with marked aggregation (especially for the reproductive phases). In Inga cayennensis, the presence of axillary inflorescences enables the production of flowers and leaves simultaneously, without the concentration of those phases. We can highlight that flowering usually occurs in the wet season or in the transition from the dry to the wet season, when the first rains and increasing temperatures act to stimulate the initiation of flowering (Souza \& Funch, 2015). The repetition of vegetative and reproductive cycles in trees and the differentiation in the positions of their inflorescences on the branches lead to different leaf rhythms and consequent changes in the architectures of the crowns of different species (Borchet, 1983). The results obtained in this study encourage continued investigations regarding the effects of the terminal or axillary positions of flowers or inflorescence on the phenological cycle of plants, which have not yet been investigated in phenological studies. 
Table 1. Circular analysis of the vegetative and reproductive phenophases of Copaifera langsdorffii Desf., Inga cayennensis Sagot ex Benth., and Senna multijuga (Rich.) H.S. Irwin \& R. C. Barneby, monitored from March/2006 to August/2008 in a fragment of cloud forest in Chapada Diamantina, Brazil.

\begin{tabular}{|c|c|c|c|c|c|c|}
\hline Studied Species & Phenophase & Mean Angle & Mean date & $\begin{array}{c}\text { Mean Vector Length } \\
(r)\end{array}$ & $\begin{array}{c}\text { Angular Standard } \\
\text { Deviation }\end{array}$ & $\begin{array}{c}\text { Rayleigh Test } \\
(p)\end{array}$ \\
\hline \multirow{4}{*}{$\begin{array}{l}\text { Copaifera } \\
\text { langsdorffii }\end{array}$} & Leaf flushing & $254.7^{\circ}$ & $14 /$ sep & 0.51 & $66.1^{\circ}$ & $<0.002$ \\
\hline & Leaf fall & $205^{\circ}$ & 23/jul & 0.15 & $110.2^{\circ}$ & 0.8 \\
\hline & Flowering & $39.6^{\circ}$ & $09 /$ feb & 0.87 & $30.0^{\circ}$ & $<0.001$ \\
\hline & Fruiting & $261.69^{\circ}$ & $21 /$ sep & 0.71 & $47.34^{\circ}$ & $<0.001$ \\
\hline \multirow{4}{*}{ Inga cayennensis } & Leaf flushing & $145.2^{\circ}$ & $27 /$ may & 0.10 & $121.1^{\circ}$ & 0.6 \\
\hline & Leaf fall & $26.5^{\circ}$ & $27 /$ jan & 0.17 & $107.5^{\circ}$ & 0.6 \\
\hline & Flowering & $237.6^{\circ}$ & 28/aug & 0.64 & $53.4^{\circ}$ & 0.1 \\
\hline & Fruiting & $92.37^{\circ}$ & 04/apr & 0.46 & $71.19^{\circ}$ & 0.2 \\
\hline \multirow{4}{*}{ Senna multijuga } & Leaf flushing & $321.9^{\circ}$ & $21 /$ nov & 0.34 & $83.0^{\circ}$ & $<0.04$ \\
\hline & Leaf fall & $248.0^{\circ}$ & $08 /$ sept & 0.55 & $61.8^{\circ}$ & $<0.001$ \\
\hline & Flowering & $55.97^{\circ}$ & $25 / \mathrm{feb}$ & 0.87 & $29.16^{\circ}$ & $<0.001$ \\
\hline & Fruiting & $123.4^{\circ}$ & 04/may & 0.85 & $31.46^{\circ}$ & $<0.001$ \\
\hline
\end{tabular}

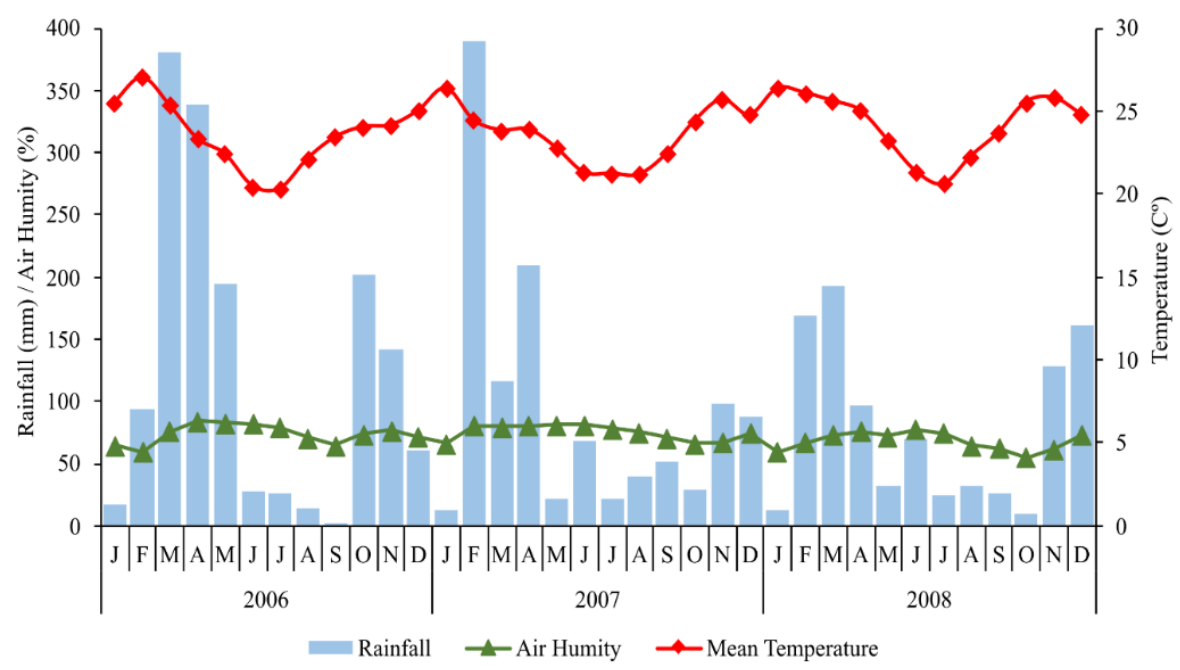

Figure 1. Monthly means of rainfall, air humitidy and temperature, from March/2006 to August/2008, in the Chapada Diamantina Mountains, Brazil (data from the local National Institute of Meteorology station).
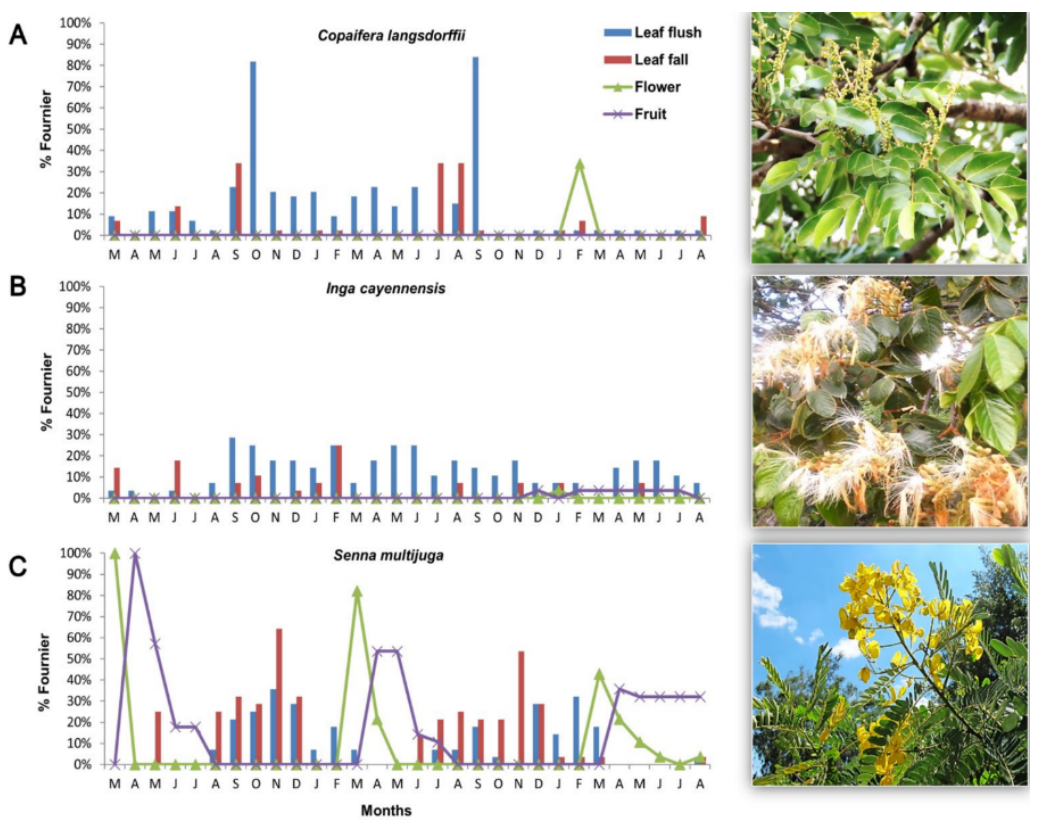

Figure 2. Leaf and reproductive phenology of Copaifera langsdorffii Desf. (A), Inga cayennensis Sagot ex Benth. (B), and Senna multijuga (Rich.) H.S. Irwin \& R. C. Barneby (C), monitored from March/2006 to August/2008 in a cloud forest fragment in the Chapada Diamantina, Brazil. 


\section{ACKNOWLEDGEMENTS}

The authors thank the graduate program in Botany (Universidade Estadual de Feira de Santana) for providing the infrastructure necessary for the monthly collections and the Fundação Chapada Diamantina for the use of their lodging infrastructure and assistance with the fieldwork.

\section{SUBMISSION STATUS}

Received: 04 Sep. 2021

Accepted: 15 Nov. 2021

Associate editor: Rodrigo Studart Corrêa (i)

\section{CORRESPONDENCE TO}

\section{Alexsandro Bezerra-Silva}

Universidade Estadual de Feira de Santana (UEFS), Br 116, Km 3, CEP 44036-900, Feira de Santana, BA, Brasil

e-mail: sandroufpecav@gmail.com

\section{AUTHORS' CONTRIBUTIONS}

Alexsandro Silva: Conceptualization (Equal); Formal analysis (Equal); Investigation (Equal); Methodology (Equal); Writing - original draft (Equal); Writing - review \& editing (Equal).

Adelly Fagundes: Conceptualization (Equal); Formal analysis (Equal); Investigation (Equal); Methodology (Equal); Writing - original draft (Equal); Writing - review \& editing (Equal).

Maria Thereza Gomes: Conceptualization (Equal); Formal analysis (Equal); Investigation (Equal); Methodology (Equal); Writing - original draft (Equal); Writing - review \& editing (Equal).

Isiara Menezes: Conceptualization (Equal); Formal analysis (Equal); Investigation (Equal); Methodology (Equal); Writing - original draft (Equal); Writing - review \& editing (Equal).

Ana Paula Couto-Santos: Conceptualization (Equal); Formal analysis (Equal); Investigation (Equal); Methodology (Equal); Writing - original draft (Equal); Writing - review \& editing (Equal).

Carliane Cerqueira: Data curation (Equal).

Lia D’Afonsêca Pedreira de Miranda: Conceptualization (Equal); Formal analysis (Equal); Investigation (Equal); Methodology (Equal); Writing - original draft (Equal); Writing - review \& editing (Equal).

Ligia Funch: Conceptualization (Equal); Data curation (Equal); Formal analysis (Equal); Funding acquisition (Equal); Investigation (Equal); Methodology (Equal); Project administration (Equal); Resources (Equal); Supervision (Equal); Visualization (Equal); Writing - original draft (Equal); Writing - review \& editing (Equal).

\section{REFERENCES}

Alvares CA, Stape JL, Sentelhas PC, Gonçalves JLM, Saparovek G. Köppen climate classification map for Brazil. Meteorologische Zeitschrift 2014; 22(6): 711-728.

Bell AD. Plant Form. An illustrated guide to flowering plant morphology. Oxford: Oxford University Press; 1991.

Borchert R. Phenology and control of flowering in tropical trees. Biotropica 1983; 15(2): 81-89.

Bortoluzzi RLC, Lima AG, Souza VC, Rosignoli-Oliveira LG, Conceição AS. 2020. Senna. In: Lista de Espécies da Flora do Brasil. Rio de Janeiro: Jardim Botânico do Rio de Janeiro 2020; [Consulted on August 06, 2021] Available at: http://floradobrasil.jbrj.gov.br/ reflora/floradobrasil/FB23149.

Costa JAS. Copaifera. In:Lista de Espécies da Flora do Brasil. Rio de Janeiro: Jardim Botânico do Rio de Janeiro 2021; [Consulted on August 06, 2021] Available at: http://floradobrasil.jbrj.gov.br/ reflora/floradobrasil/FB22895.

Fournier LA. Un método cuantitativo para la medición de características fenológicas em árboles. Turrialba 1974, 24, 422-423.

Garcia FCP, Bonadeu F. Inga. Lista de Espécies da Flora do Brasil. Rio de Janeiro: Jardim Botânico do Rio de Janeiro 2021; [Consulted on August 06, 2021] Available at: http://floradobrasil.jbrj.gov.br/ reflora/floradobrasil/FB22803.

Morellato LPC, Alberti LF, Hudson IL. Applications of circular statistics in plant phenology: a case studies approach. In: Keatley M, Hudson IL. Editors. Phenological Research: Methods for Environmental and Climate Change Analysis. Heidelberg: Springer; 2010.

Morellato et al. 2016. Linking plant phenology to conservation biology. Biological Conservation 2016; 195: 60-72.

Orellana JT, Nascimento JOV, Grilo J, Neves SPS, Miranda LAP, Funch LS. Seasonality and the Relationships Between Reproductive and Leaf Phenophases In Myrtaceae Using Field and Herbarium Data. Floresta e Ambiente 2021; 28(1): e20200035.

R Core Team. 2014. R: a language and environment for statistical computing. Vienna, R Foundation for Statistical Computing.

Santos MGM, Miranda LAP, Funch LS. Comparing Data Collection Methods in Phenological Evaluations of Himatanthus drasticus. Floresta e Ambiente 2021; 28(2): e20200060.

Souza IM, Funch LS. Fenologia e modos de polinização e dispersão de Fabaceae em floresta ciliar, Chapada Diamantina, Nordeste do Brasil. Sitientibus serie Ciencias Biologicas 2015; 15: 1-10.

Weberling F. Morphology of flowers and inflorescences. Cambridge: University Press; 1989.

Zar JH. Biostatistical analysis. New Jersey: Prentice-Hall; 2010. 